\title{
CONSTRUIREA LOGICĂ A UNUI DEMERS DE PROIECTARE
}

lect. dr. arh. Andrei Mitrea, asist. dr. urb. Dana Milea

Universitatea de Arhitectură și Urbanism „Ion Mincu”, București

andrei.mitrea@uauim.ro,dana.milea@uauim.ro

\section{Tema de proiectare}

În arhitectură și urbanism, un program reprezintă:

„Ansamblul de exigențe ce trebuie satisfăcute astfel încât construcțiile să corespundă destinației lor."

(Bălan și Mihăilescu (coord.), 1988: 180).

Un proiect este un caz particular de ilustrare a unui program. Un proiect bun este rezultatul unei teme de proiectare bune, iar o temă de proiectare bună respectă o condiție fundamentală:

\section{Ea formulează clar problema care trebuie rezolvată.}

O problemă este formulată clar doar atunci când reușim să o descriem limpede și când putem să construim testul pe care trebuie să îl treacă o propunere pentru a putea fi considerată soluție (cf. McCarthy, 1956 apud. Newell și Simon, 1972). Prin urmare, condiția de mai sus produce două consecințe:

\section{_ Numirea problemei;}

_ Stabilirea condițiilor minime care validează soluția.

În practică, aceste condiții interpretează datele generale ale programului, descriu în detaliu procesele funcționale specifice și toți participanții la ele, fac referire la toate spațiile, precizând dimensiunile lor, finisajele, echipamentele tehnice, în relație cu caracteristicile reliefului, cu forma, cu orientarea și cu echiparea amplasamentului (cf. Bălan și Mihăilescu (coord.), 1988: 180f).

Stabilirea conținutului temei de proiectare, adică a datelor de temă, este un moment cheie, deoarece el fixează așteptările pe care le avem de la proiect. Dacă schimbăm datele de temă după ce am început să lucrăm la propunerea de rezolvare, vom ajunge cel mai probabil să modificăm propunerea făcută, fie parțial, fie complet (cf. Cardaș, 1983).

În stabilirea condițiilor din tema de proiectare, pe lângă setul de argumente extrase din analize, din sinteză și din diagnostic, mai lucrăm cu încă două instrumente, pe care le discutăm, pe scurt, în continuare:

_ Principiile de proiectare;

_ Manualele de proiectare. 


\section{Principiile de proiectare}

Un principiu este o idee, considerată adevărată și valoroasă, care stă la baza deciziilor pe care le luăm în construirea și în validarea soluției. Rolul principiilor este simplu: ele ne ușurează procesul de proiectare, oferindu-ne puncte de sprijin suplimentare în luarea deciziilor. În plus, în prezentarea proiectului, expunerea principiilor, la fel cum vom vedea că se întâmplă și în cazul conceptelor, dă posibilitatea colegilor, echipei de îndrumare sau comisiei să înțeleagă mai bine ideea proiectului și argumentația din spatele ei.

Principiile pot avea un caracter general sau pot face referire la aspecte specifice, ajutându-ne să gestionăm nu doar conținutul soluției, ci și calea pe care ajungem la ea. Astfel, putem formula principii de naturi diferite:

_ Principii care ghidează în principal conținutul soluției:

„improve the environment whenever you do anything to change it."

(Garrett Eckboa apud. Simonds și Starke, 2006: 101).

_ Principii care ghidează mai degrabă modul de lucru:

„Pentru a realiza un proiect pe un sit în mod eficient, trebuie să înțelegem pe deplin programul, să fim pe deplin conștienți de proprietățile fizice ale locului și de ambianța totală a acestuia."

(Simonds, 1967: 69).

_ Principii care ghidează deopotrivă conținutul soluției și modul de lucru:

„fiecare element trebuie să fie dezvoltat în corelație studiată cu ansamblul sitului și cu zonele imediat învecinate"

(Simonds, 1967: 90).

În alegerea principiilor de proiectare apare o problemă de optim, similară cu cea întâlnită la alegerea analizelor potrivite. Astfel, trebuie găsit numărul minim de principii, care să aibă efectul maxim asupra proiectului. Deoarece suita de principii este cumulativă, ele nu trebuie să se contrazică. La final, rezolvarea problemei trebuie să respecte toate principiile. Altfel spus, nicio decizie luată nu trebuie să încalce vreun principiu. Din acest motiv, ele trebuie alese cu atenție și formulate foarte limpede.

\section{Manualele de proiectare}

Manualele de proiectare oferă informații detaliate și specifice despre modul în care funcționează în realitate proiectele reprezentative pentru un program. În alcătuirea datelor de temă, informațiile extrase din manualele de proiectare sunt complementare principiilor de proiectare.

Valoarea manualelor constă atât în informațiile calitative și cantitative oferite, structurate adesea în ansambluri de reguli care trebuie respectate de un proiect, cât și în expunerea procesului logic care stă în spatele funcționării proiectului și al justificării nevoii de a impune o suită de reguli proiectului respectiv. Ultimul aspect va deveni esențial ulterior, când vom face trecerea de la tema de proiectare la rezolvarea ei. 
Deoarece problemele pe care le rezolvăm prin proiecte, în general, presupun intervenții în mai multe domenii, iar manualele, de cele mai multe ori, tratează subiecte specifice, vom consulta doar manualele de care avem nevoie, pentru a acoperi gama de situații cu care ne confruntăm. Acest pas face parte din analiza critică a bibliografiei și răspunde următoarelor întrebări de cercetare:

_ Cât de bine seamănă situația din proiect cu cea din manual?

- Există date de temă pentru care nu am găsit un corespondent în manualele de proiectare? Cât de importantă este ponderea lor în economia proiectului?

\section{De la tema de proiectare la soluție}

Cu cât o temă de proiectare este mai precisă și mai completă, cu atât trecerea la rezolvarea ei și la construirea propunerii este mai ușoară.

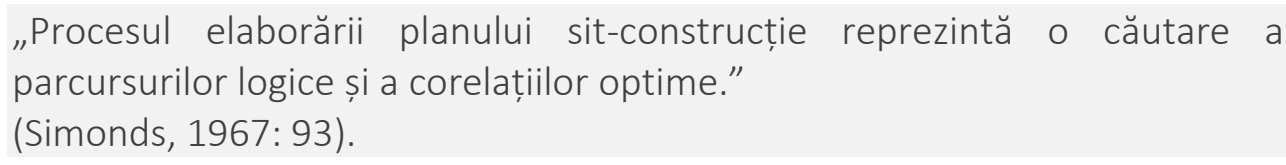

În aceste condiții:

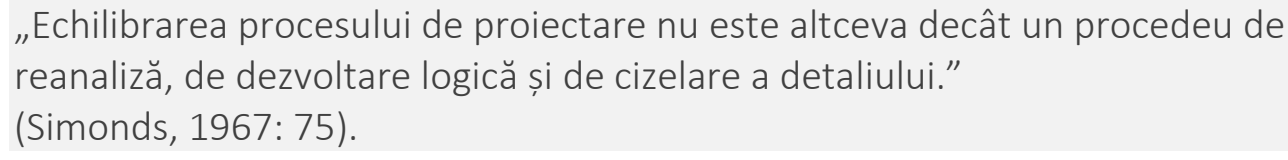

La primele proiecte, construirea propunerii va fi un proces anevoios, poate chiar mai anevoios decât alegerea analizelor. Cu un exercițiu suficient însă, vom îmbunătăți simțitor capacitatea de a echilibra procesul de proiectare.

Uitați-vă la următoarele patru scheme. Ele înfățișează un exemplu de succesiune incompletă de salturi, de la elementele de analiză la propunere. Ilustrațiile nu prezintă demersul integral al proiectului și nici nu respectă în detaliu toți pașii descriși în acest capitol. Totuși, chiar și în aceste condiții, putem deduce o trecere coerentă de la elemente de analiză, la elemente de sinteză, de diagnostic, de temă și, în final, de propunere. Ba, mai mult, intuim ușor o parte din firul argumentării proiectului, referitoare la relațiile create între propunerea făcută, caracteristicile terenului și echiparea sitului. În cazul proiectelor voastre, demersul nașterii propunerii trebuie prezentat mai consistent de atât, în întregime și fără salturi logice.

După definitivarea propunerii, ea trebuie trecută prin testul condițiilor expuse în tema de proiectare. Dacă le îndeplinește integral și trece testul, înseamnă că am rezolvat problema. Dacă nu, ne întoarcem câțiva pași și facem modificările necesare pentru a răspunde condițiilor de validare.

Avem aici două întrebări de verificare folositoare:

_ Soluția respectă toate condițiile din tema de proiectare?

_ Putem să ajungem mai ușor la o soluție mai elegantă? 


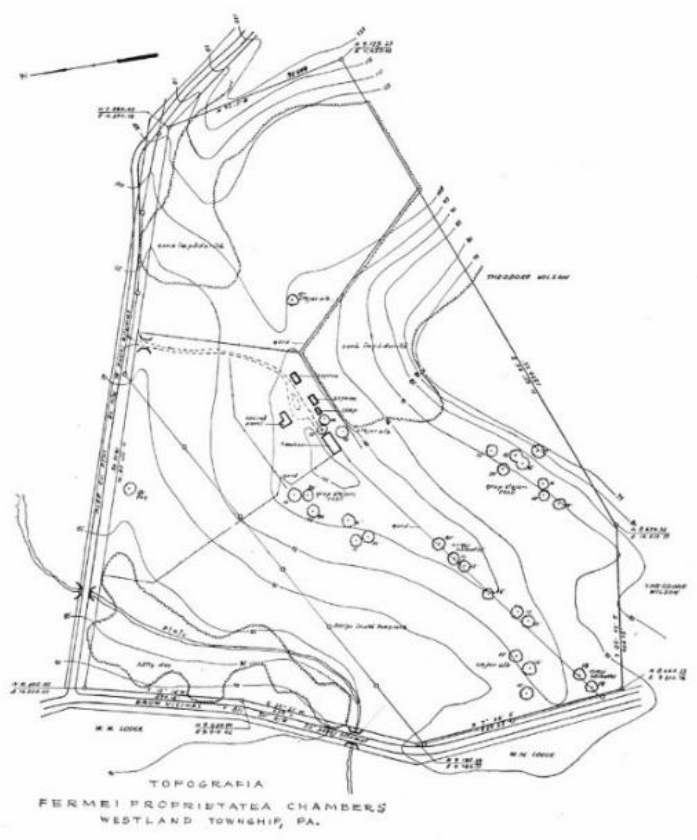

O primă lectură a topografiei amplasamentului Sursa: Simonds, 1967: 70

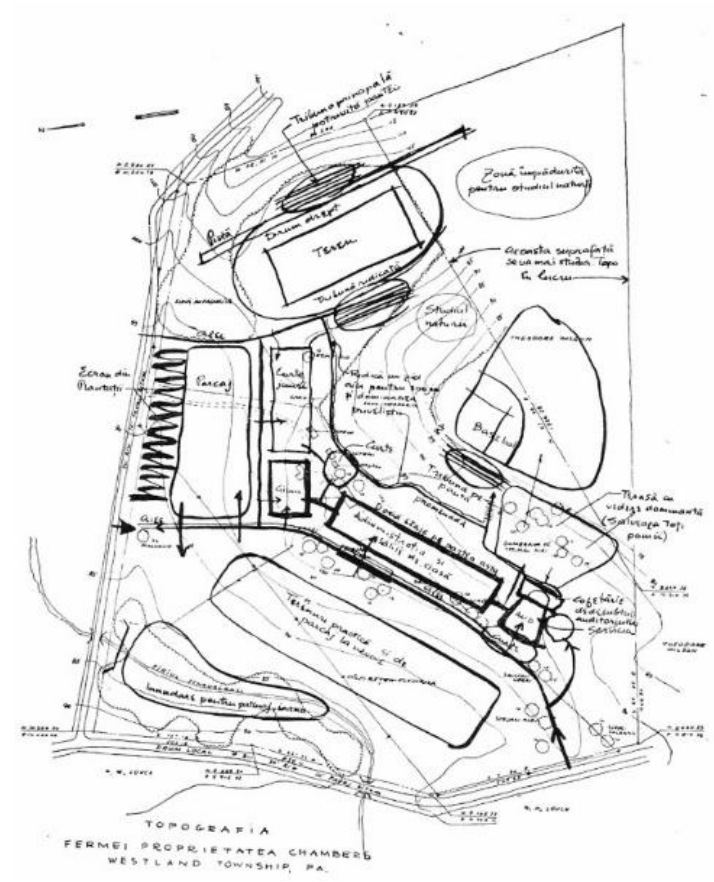

Schema relației construcție - amplasament, varianta 1 Sursa: Simonds, 1967: 72.

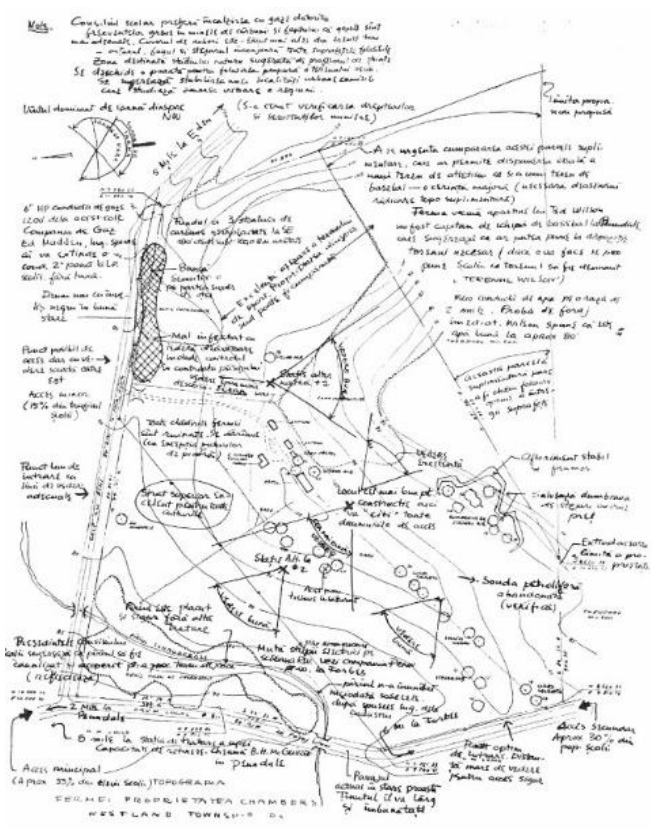

Schema amplasamentului

Sursa: Simonds, 1967: 71.

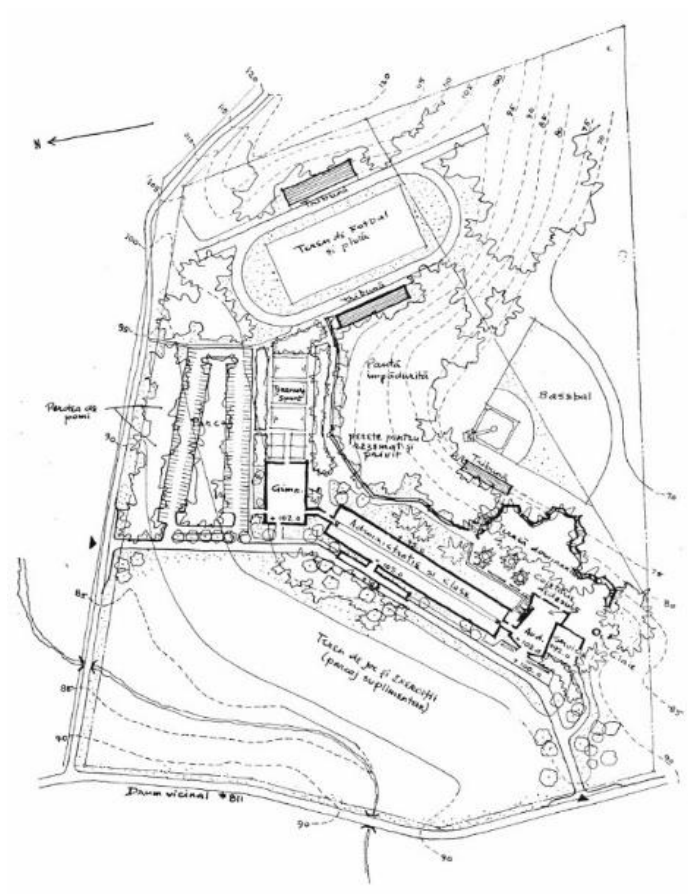

Schema relației construcție - amplasament, varianta 1 reluată și rafinată Sursa: Simonds, 1967: 73. 


\section{Referinţe}

Bălan, Ș. și Mihăilescu, N. Ș. (coord.) (1988), Lexicon de construcții și arhitectură. Volumul III. București: Editura Tehnică.

Cardaș, M. (coord.) (1983), Mic lexicon ilustrat al noțiunilor de sistematizare. București: Editura Tehnică. Newell, A. și Simon, H. (1972), Human problem solving. Englewood Cliffs, N.J.: Prentice-Hall.

Simonds, J. O. (1967), Arhitectura peisajului. București: Editura Tehnică.

Simonds, J. O. și Starke, B. W. (2006), Landscape architecture - A manual of environmental planning and design. New York (NY): McGraw-Hill. 